CURRENT RESEARCH JOURNAL OF PHILOLOGICAL SCIENCES

(ISSN -2767-3758)

VOLUME 03 ISSUE 01 Pages: 82-87

SJIF IMPACT FACTOR (2021: 5 . 823)

OCLC - 1242423883 METADATA IF - 6.925
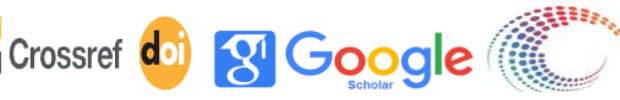

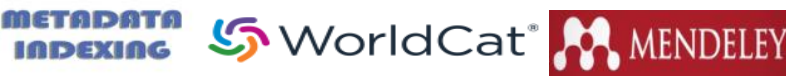

Publisher: Master Journals

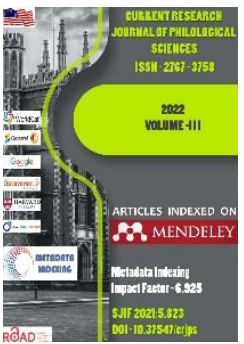

Journal Website: https://masterjournals. com/index.php/crips

Copyright: Original content from this work may be used under the terms of the creative commons attributes 4.0 licence.
Research Article

\section{NON-COMMUNICATION IN THE NAMING OF A WORK OF ART AND ITS FEATURES}

\author{
Submission Date: January 11, 2022, Accepted Date: January 21, 2022, \\ Published Date: January 31, 2022 \\ Crossref doi: https://doi.org/10.37547/philological-crjps-03-01-14 \\ Umidjon Usubovich Ahmedov \\ Lecturer Of The Department Of Interfaculty Of Foreign Languages Kokand State Pedagogical Institute \\ Named After Mukimi, Uzbekistan
}

\title{
ABSTRACT
}

This article addresses the issue of non-communication in the naming of a work of art and its features in the interpretation of the process in modern linguistics. In addition, an attempt is made to analyze and study anthroponyms and phrases, analogies and metaphors in the Uzbek language as lingvocultures, which are the object of science. The interpretation of the nomination process in modern linguistics is mutually adequate (similar) in terms of semantic features, some of which are not only in terms of content, but also in terms of external structure and form.

\section{KEYWORDS}

Linguoculturology, paremiology, anthroponym, adequate.

\section{INTRODUCTION}

During the years of independence, the Republic of Uzbekistan has created a stable system of organization, organization, management and financing of research activities. The country has a multidisciplinary scientific and organizational infrastructure in the form of potential scientific schools, scientific laboratories and departments, higher education and research institutions, ministries and departments, as well as scientific, technical and expert councils throughout the country. The 


\section{CURRENT RESEARCH JOURNAL OF PHILOLOGICAL SCIENCES}

(ISSN -2767-3758)

VOLUME 03 ISSUE 01 Pages: 82-87

SJIF IMPACT FACTOR (2021: 5. 823)

OCLC - 1242423883 METADATA IF - 6.925

\section{Crossref

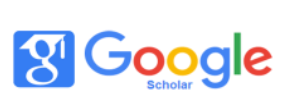

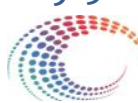

metapata

5. WorldCat fి̂ MENDELEY

Publisher: Master Journals

resolution of the President of the Republic of Uzbekistan Shavkat Mirziyoyev "On measures to further improve the activities of the Academy of Sciences, the organization, management and financing of research" is a logical continuation of work in this direction and marks an important stage in solving existing problems.

In fact, fundamental research plays an important role in the development of science, while imagining the development of the country without science. It is through them that new knowledge is acquired and markets are formed, creating a solid foundation for future applied research and innovation.

It is no coincidence that the development of scientific research and innovation is reflected in the Action Strategy for the five priority areas of development of the Republic of Uzbekistan for 2017-2021. After all, this area will be a priority in public policy for five years.

It should be noted that scientific research activities in the Republic The Law of the Republic of Uzbekistan "On Education" and the "National Program of Personnel Training", the Action Strategy of the President of the Republic of Uzbekistan for 2017-2021 on the priority areas of development of the Republic of Uzbekistan "Active Entrepreneurship. Decree No. PF-5 308 of January 22, 2018 "On the State Program for the implementation of the Year of Support of Innovative Ideas and Technologies", PQ-2789 of February 2, 2017 "On the activities of the Academy of Sciences, the organization and management of research Resolution of the President of the Republic of Uzbekistan dated May 11, 2016 "On measures to further improve funding"»

Along with the implementation of the Resolution No. PP-2527 "On measures to further improve the activities of the National University of Uzbekistan",
PQ-2909 dated April 20, 2017 "On measures to further develop the system of higher education", the university has fundamental, practical and The development of innovative research, the organization of research in promising and advanced scientific areas, the support and coordination of work on the support and implementation of innovative ideas and developments of young scientists and talented students are topical issues of today.

Based on the above Presidential decisions, it should be noted that the period of development of modern linguistics is characterized by a growing interest in comparative-typological research. It is a law of nature, due to the nature of the use of languages, social life, the interdependent movement of languages, and their interaction with one another. Therefore, any research devoted to comparative analysis has scientific and practical significance.

\section{MATERIALS AND METHODS}

In the context of modern linguistics, the comparative study of languages is expanding and all languages are structural surfaces are covered. The study of word semantics, aimed at the analysis of the content scale of lexical units based on the teachings of $F$. de Saussure, is becoming the object of special and comparative-typological research. J.Buronov, M.Abdurazzakov, O.Yusupov, M.Umarkhojaev, A.Mamatov, D. Ashurova, Sh.Safarov, A.Sheremetova. M.Rasulova, G.Hoshimov, L.Tener, L.Elmslev, R.Meer, V.Porsig, L.Weisgerber, S.Ulman, ILrir and others who developed in different directions.

However, despite the significant shortcomings in the study of works of fiction, modern semantics, including comparative semantics, deals with systematic relationships, the semantic merging of classes within a name-subject, semantic groups, research, 


\section{CURRENT RESEARCH JOURNAL OF PHILOLOGICAL SCIENCES}

(ISSN -2767-3758)

VOLUME 03 ISSUE 01 Pages: 82-87

SJIF IMPACT FACTOR (2021: 5 . 823)

OCLC - 1242423883 METADATA IF - 6.925

\section{Crossref

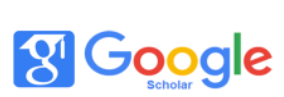

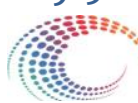

metapata

5. WorldCat ${ }^{*}$ भ̂े MENDELEY

Publisher: Master Journals

identification of semantic groups, internal and external to study their internal connections and relations in terms of interlinguistic relations, to reveal the hierarchical relations between the components of their semantic group, to clarify their systems, to identify the semantic components that make up a single semantic group and, of course, to identify similarities and differences giving is of great importance.

In our view, the attempts of some linguists to substantiate the national identity of knowing the world by the names of works of art further complicate the solution of this problem. Where there is no historical or factual material, some researchers have linguistically systematized the experience of man by observing, seeing, and defining it as the names of works of art try to cite it as evidence of exotic material observed in culture. The model of scientific perception, which is closely connected with intuition and mental cognition of an objective being, consists of a transitional stage, followed by the need to express the being in an artistic way, which indicates that language is fully formed. Referring to history should serve as one of the arguments used in these cases to confirm, reinforce the general idea. In this case, in the process of non-communication, language must manifest itself as the creator of the Facebook model, and as a result, it must become an independent force of "linguistic cognition." This does not correspond to the assertion that the original judgment, that is, the material form of consciousness. The subjective nature of language becomes the decisive force of knowledge, and its structure turns out to be immanent, essentially hereditary, innate. Creating knowledge, information, knowledge of objective existence. and is designed to perform the transmission function. The language system itself contains this linguistic commonality that emerges in the process of knowing existence. In language, the system of concepts expressed by words that are the names of works of art expresses such complex connections of concepts that their complex use allows to convey the content of human thought in different ways, that is, using simple and figurative definitions. This is the peculiarity of language, that is, language is a tool for the formation of thought, the type can be not only a means of storing knowledge, but also a way of expressing it with the dynamics of its development. From a semantic point of view, different national languages, from the point of view of naming works of art, turn out to be different variants of the nominal structure, the potentially unique whole. It had a self-regulating, two-sided character. The system of language, which manifests itself as a system of signs and serves to form and convey thought in its complex application, is created by knowing the image of the world created in works of art, not language, without looking at it as a "linguistic image of being" taking a more rigorous approach to this, the image presented by the author using the title of the work of art can only be created using the ideal full text, universal language. The accuracy of the results of knowledge of the conceptual systems of national languages is not comparable in quality or level of the names of works of art. These systems, on the other hand, are considered to be different variants of a single universal human language, and their content is historically flawed this activity stems from the lingvoculturological nature. In this regard, from the point of view of the theory of linguistic relativity, it is not methodologically correct to compare the events of a particular language separated from different languages to the information in the name of works of art in order to solve the problems of semantics of works of art. Here, basically, two serious mistakes are made, which are not difficult to perceive not only by 


\section{CURRENT RESEARCH JOURNAL OF PHILOLOGICAL SCIENCES}

(ISSN -2767-3758)

VOLUME 03 ISSUE 01 Pages: 82-87

SJIF IMPACT FACTOR (2021: 5. 823)

OCLC - 1242423883 METADATA IF - 6.925

an expert who has studied the problem in depth, but also by an ordinary reader.

These are:

a) The first mistake is to try to compare the linguistic facts in the names of the studied fiction directly with the existing things in the material being, rather than with the system of concepts.

b) the second error is the analysis outside the system of one or another form of language, in other words, the close interdependence and compensation of lexical, grammatical and other means prevailing here due to the lack of influence of the complex mechanism of language on the analysis is completely.

The first error leads the authors to the conclusion that the linguistic style of the world is reflected in the names of works of art. In fact, the linguist, capable of expressing any concept, had to show the peculiarities of concrete forms in the general language system, including the name of works of art.

The second error distorts the essence of language, denying the possibility of analyzing the language as a whole system in the analysis of the name of works of art, in which only this or that part of the language is analyzed in an unsystematic way and unreasonably compared to other languages.

In such cases, the above hypothesis is based on the difficulties encountered in the process of translating the names of works of art from one language to another, and on the loss of the psyche in translation, especially in translating its name, often in the translation of poetic works.

All of them are methodologically incorrect in the case of comparing the names of works of art, because the method of proof cannot be applied to language. For example, the fact that there is an article in German does not mean that Germans perceive objects according to some gender-related traits. It is incorrect to conclude that Abkhaz speakers with a similar ergative structure are incapable of distinguishing between subject and object actions in existence.

The Uzbek and Russian words for "q'ol" are pronounced with the English words "hand", "arm", and the Uzbek words "kaptar" and "musicha" are given with the same word "taube" in german cannot be distinguished from each other ored may not result. Because in practice, the Germans do the same thing as the Uzbeks do the difference between kaptar and musicha.

The fact that the word "know" in Uzbek is given in German with the verbs "wissen", "kennen" does not mean that the Germans know more about the Uzbeks in Karaganda, or understand different types of knowledge. The fact that the word "lunch" in English is translated into Uzbek by such figurative means as "just breakfast", "second breakfast", "eleven", "light lunch" does not mean that Uzbeks could not understand this concept.

When comparing the meanings of words in two or more languages from the following perspectives and observing inconsistencies in meanings, linguists come to the "universal" conclusion that "the conceptual apparatus of peoples speaking different languages is different."

The national identity of the conceptual semantic content of language units when they are the names of works of art does not rule out the possibility of complex semantic complexes in the sentence structure of the work of art, which may be similar in different languages depending on the meaning. Due to the objectivity of the conceptual form understood 


\section{CURRENT RESEARCH JOURNAL OF PHILOLOGICAL SCIENCES}

(ISSN -2767-3758)

VOLUME 03 ISSUE 01 Pages: 82-87

SJIF IMPACT FACTOR (2021: 5. 823)

OCLC - 1242423883 METADATA IF - 6.925

in the name of a work of art, the national specificity of the pragmatic and semantic side of the name of a work of art written in a language cannot be a source for the subjective element of the cognitive process.

However, there is another aspect of the national identity of the semantics of the name of a work of art, which is related to the specificity of motivation in choosing the form of sound in the process of language development. distinguishing characters characterize the meaning being motivated. The fact that the sound content remains the same in different languages is different from the differences and this external similarity is thought to indicate that an "additional national identity" is being formed. For example, the English "head" - the front of the ship the nose; head - nail cap; head - the top of the milk, cream. The subjective property in linguistic meanings expressed by the title of this work of art does not apply to the denotation of the denotation itself. In all cases, the corresponding physical event is determined by the sign of one of its signs. The choice of this symbol depends on the specifics of the English or Uzbek language.

The national and subjective facts of language, which are closely related to etymology, cannot deny the main idea that "in all languages the relationship between the defining and defining elements is the same, and as a result the image of the object is given the correct name of the work of art in our case." Thus, just as there is no need to oppose the conceptual model of the world (DKM) expressed in the name of a work of art as an additional element of knowledge acquired through pure sensual and mental intuition, the information related to sensual and mental intuition in language adds to the rational elements of language and the fact that it does not agree with the idea that the names of works of art are reflected in it is of a unique epistemological essence.

"The basis of the DKM is the information given in the concepts that represent the names of works of art, and the basic information in the DLM is the knowledge available in words and phrases in specific spoken languages. According to Sepir-Whorf's theory of additional national subjective information brought in by TLM, it is incorrect to equate words and phrases expressing the name of works of art with specific information brought by language into the linguistic landscape of the world. Because TLM has been associated not only with the lexical but also with the grammatical aspect of this hypothesis. Therefore, grammatic the information expressed by cannot be excluded.

\section{CONCLUSION}

Many researchers have repeatedly referred to the theory of relativity and, in particular, the Sepir-Wharf hypothesis in the study of the semantics of the names of works of art. However, they were unable to find evidence, either theoretically or experimentally, to serve his defense. Well-known scholar E. Lenneberg, concluding his discussion of the experimental study of the Sepir-Wharf hypothesis, was compelled to conclude that the title of the work of art was "very little proof of the violent judgment of the word on knowledge." Concrete research in this area, that is, on the semantic and pragmatic aspects of the title of a work of art, also showed that the results of semantic experiments in this area do not correspond to reality in its classical form.al tools from the information entered by ÍTLM in the name of works of art.

\section{REFERENCES}


CURRENT RESEARCH JOURNAL OF PHILOLOGICAL SCIENCES

(ISSN -2767-3758)

VOLUME 03 ISSUE 01 Pages: 82-87

SJIF IMPACT FACTOR (2021: 5 . 823)

OCLC - 1242423883 METADATA IF - 6.925

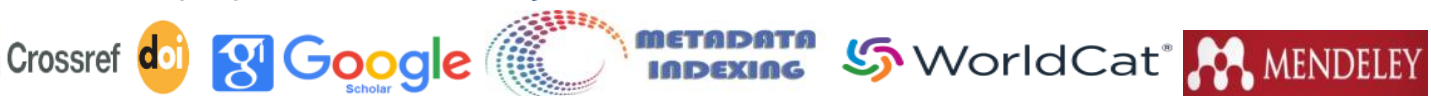

12. Umidjon, A. (2020). Reading techniques in efl teaching. Asian Journal of Multidimensional Research (AJMR), 9(5), 108-111.

2. Ekman, W.V. Friesen. - New Jersey :

Prentice-Hall, Inc., Englewood Cliffs, 1975. -

$212 \mathrm{p}$

3. Trier J. Der Deutsche Wortschatz im Sinnbezirk des Verstandes.(Die Geschichte eines sprachliches Feldes). Bd 1. Heidelberg, 1931;

4. Ipsen G. Der alle Orient und die Indogermanen."Stand und Aufgaben der Sprach wissenschaft"? Festschrift fur W. Streitberg. Heidelberg, 1924.;

5. Porzig W. Das Wunder der Shprache (Probleme, Methode, und Ergebnisse der modemen Sprachwissenschaft), 2. Aufl. Bern, 1957.

6. Гулыга Е.В., Шендельс Е.И. Грамматиколексические поля в современном немецком языке. М., 1969. 183 С.

7. Нурмонов А. Танланган асарлар. Уч жилдлик 1 жилд. Тошкент: “Академнашр"2012

8. Собиров А.Ш. Ўзбек тили лексик сатхини системалар системаси тарзида ўрганиш. T., 2004;

9. Рахмонбердиев К. Глаголы зрительного восприятия в узбекском языке. Автореферат дисс... канд. филол.наук.Ташкент,1969;

10. Искандарова Ш. Тил системасига майдон асосида ёндашув., Т., 2007.

11. Ahmedov, U. (2019). INTERACTION PATTERNS IN ELT TEACHING: GROUP WORK AND PAIR WORK. Theoretical \& Applied Science, (12), 170-172. 